\title{
Analysis Of Anxiety Levels Of Pregnant Women During The Covid-19 Pandemic In Indonesia
}

\author{
Gusriani Sabrin ${ }^{1 *}$, Yuni Retnowati ${ }^{2}$, Nur Indah Noviyanti ${ }^{3}$, Wahida Sunardi ${ }^{4}$, Darmiati Sutrang ${ }^{5}$ \\ 1,2 ,3Faculty of health sciences, Borneo Tarakan University, North Kalimantan, Indonesia \\ ${ }^{4}$ Midwifery Department, Health Polytechnic of Ministri of Health in Mamuju, West Sulawesi, Indonesia \\ ${ }^{5}$ Midwifery Department, Institut Ilmu Kesehatan, South Sulawesi, Indonesia \\ *Corresponding Author: \\ rhyagusriani68@gmail.com
}

\begin{abstract}
.
Coronavirus Disease 2019 (Covid-19) is a new type of disease caused by the Sars-CoV-2 virus. The unpredictability of the Covid-19 pandemic makes people prone to severe anxiety. Anxiety is a normal reaction to uncertainty and things that may harm. Research has shown that pregnant women are especially prone to anxiety with the prevalence of gestational anxiety. The impact of the COVID-19 pandemic on pregnancy-related anxiety has yet to be systematically studied. This research aims to assess the level of anxiety of pregnant women during the Covid19 pandemic and to analyze the causes. This type of research is descriptiveanalytic with the cross-sectional approach. The study was conducted in MarchApril 2020 with a total of 154 pregnant women respondents from various regions in Indonesia. The results showed that the majority of respondents were not anxious, namely 89 respondents $(57.8 \%)$, respondents with mild anxiety were 58 respondents $(37.7 \%)$, moderate anxiety was 5 respondents $(3.2 \%)$ and severe anxiety was 2 respondents $(1.3 \%)$. The low rate of anxiety in pregnant women during the Covid-19 pandemic was due to the availability of information about the causes, modes of transmission, and massive prevention of Covid-19 through various media as well as guaranteed services and availability of health facilities.
\end{abstract}

Keywords: Covid-19, Anxiety, Pregnancy

\section{INTRODUCTION}

Coronavirus disease 2019 (Covid-19) is a new type of disease caused by the Sars-CoV-2 virus (1). Covid-19 has spread to various countries in the world including Indonesia so that WHO declared COVID-19 a global pandemic on March 11, 2020 (2). Although they have made promotional, preventive, and curative efforts, various countries continue to look for the number of cases and deaths per day. It was recorded that until April 28, 2020, 2,883,603 people in the world were confirmed to have been infected with COVID-19, with 198,842 deaths. In Indonesia, the number of cases of Covid-19 on the same date was 9,511 with 772 deaths $(3,4)$ Most cases of Covid-19 have been confirmed with mild symptoms and some cases with severe infections that cause serious lung disease. Covid-19 can affect all individuals, especially someone with a vulnerable condition and risk factors (5). There is no valid information available on pregnant women and their complications. But given previous epidemics (SARS and MERS), as well as mental and physical changes during pregnancy, pregnant women are considered at high risk of contracting infectious diseases during outbreaks $(6,7)$. The unpredictability of the Covid-19 pandemic makes people prone to severe anxiety. Anxiety is a normal reaction to uncertainty and things that may harm. Anxiety is a feeling of worry, nervousness, or unease about something with an uncertain outcome and it can co-exist, predispose, or cause depression.

Research has shown that pregnant women are especially prone to anxiety with a prevalence of gestational anxiety between $15 \%$ and $23 \%$, in comparison with 3 to $5 \%$ of anxiety symptoms in the general population $(8,9)$.Pregnancy is a period in which physiological, psychic, hormonal, and social changes are present, increasing the risk of emotional suffering and psychiatric morbidity in this stage of a woman's life. The evidence suggests that the likelihood of anxiety during pregnancy increases in cases of psychiatric comorbidity, stressful events, social disadvantage, history of abortion, fetal loss, preterm delivery or early neonatal loss, previous history of mental illness, or a history of psychiatric treatment during an earlier 
pregnancy or throughout life. Considering the belief among many societies that the psychological state of the mother can affect the child in her womb, anxiety disorder is considered one of the risk factors in pregnancy development, since its onset may compromise the fetus in being associated with negative neonatal outcomes, such as prematurity, low birth weight, lower Apgar scores, fetal development deficit, in addition to lasting effects on the physical and psychological development of the child and obstetric complications, such as vaginal bleeding and the risk of abortion (10-12).

The study conducted by Fakari and Simbar has summarized several reasons pregnant women feel worried during the Covid-19 pandemic, including. 1) many pregnant women have had a birth plan before the pandemic, but are currently worried about how their families will be present, given the urban and quarantine constraints; moreover, even if there is no inter-urban restriction, they may be worried about their families being infected during transportation. 2) Many pregnant women do not go to visit their physicians due to concerns that they may be exposed to the Coronavirus in the hospital environment or on the way to the hospital and maybe post-term. Or on the contrary, due to stress and worry, they want an early termination and elective cesarean section. 3) Some mothers are worried about their fetal or their neonate being born. Also, some mothers worry about postpartum such as breastfeeding, and neonatal care (7).A preliminary study examining the effects of the Covid-19 pandemic on the symptoms and symptoms of pregnant women shows the effects of the Covid-19 pandemic on recording and depression in pregnant women (6) but the impact of the COVID-19 pandemic on anxiety-related pregnancies has not been studied systematically (13) therefore it is necessary to conduct a deeper study of the impact of Covid-19 on pregnant women victims. This study aims to assess the level of pregnant women during the Covid-19 pandemic in Indonesia and to analyze the contributing factors, namely pregnancy, education, employment, and the area of domicile of pregnant women.

\section{METHODS}

This type of research is descriptive-analytic with a cross-sectional approach. Data will be collected through an anonymous web-based survey made up of closed questions with multiple choice answers. The survey has two parts:

1) Questions related to general demography, pregnancy health history, and socioeconomic factors.

2) Hamilton Anxiety Rating Scale (HARS) questionnaire for anxiety assessment

The survey collects information on demography, socioeconomic situation, pregnancy health question. HARS scales are used to assess anxiety. The survey consists of 25 questions, and it has the following structure: consent form, demographic and socioeconomic questions, pregnancy health questions, and the HARS scales. Before filling out the questionnaire that was spread boldly using the google form. Respondents were given the option to provide personal contact information (name and email address).

The study was conducted on March 31,2020, to April 30, 2020. The population in this study were all pregnant women in Indonesia until April 2020. However, because the population of pregnant women in Indonesia is unknown, the calculation of the sample size uses the Lemeshow formula. Based on the results of calculations with the formula, the number of samples needed in this study was 96 respondents. Respondents were collected by means of an online HARS questionnaire in the form of Google. The number of respondents collected until the end of the study was 154 respondents.Data will be kept anonymous and nonidentifiable. The data were processed using the Statistical Package for Social Sciences (SPSS) program for Windows version 22.0 which was then analyzed using the chi-square test.

\section{RESULTS AND DISCUSSION Results}

The study was conducted on March 31, 2020, to April 30, 2020, with the aim of assessing the level of anxiety in pregnant women in Indonesia during the COVID-19 pandemic and analyzing the factors that cause it. After distributing the HARS questionnaire online, there were 154 respondents from various regions in Indonesia. The research results are presented as follows: 


\section{Respondent response rate}

Table 1 shows the distribution of respondents based on the anxiety level of respondents. The number of respondents in the category "no anxiety" has the highest number namely 89 respondents $(57.8 \%)$. The number of respondents with mild anxiety were 58 respondents $(37.7 \%)$ then followed by 5 respondents $(3.2 \%)$ for moderate anxiety and 2 respondents $(1.3 \%)$ for severe anxiety.

Table 1. Respondents distribution data based on anxiety level

\begin{tabular}{lcc}
\hline \multicolumn{1}{c}{ Anxiety level } & Frequency (n) & Presentase (\%) \\
\hline No Anxiety & 89 & 57.8 \\
Mild Anxiety & 58 & 37.7 \\
Moderate Anxiety & 5 & 3.2 \\
Severe Anxiety & 2 & 1.3 \\
Total & 154 & 100 \\
\hline
\end{tabular}

Source: Primer data, May 2020

Data shows that even though, during the COVID-19 pandemic, more than $50 \%$ of pregnant women were in a state of no anxiety

\section{The rate of sacrificing pregnancy}

According to the results of statistical tests with the characteristics of gestational age, it revealed that the majority of respondents in the first trimester of pregnancy were 80 respondents (51.94\%) with 1 respondent (1.2\%) for a severe anxiety level and 3 respondents $(3.8 \%)$ for moderate anxiety. Respondents in trimester II of pregnancy were 38 respondents $(24.67 \%)$ with 1 respondent $(2.6 \%)$ for moderate anxiety level and 12 respondents $(31.6 \%)$ for mild anxiety level. Respondents in trimester III of pregnancy were 36 respondents $(23.37 \%)$ with 1 respondent $(2.8 \%)$ for severe anxiety and 1 respondent $(2.8 \%)$ for moderate anxiety.

Tabel 2. Distribution of anxiety levels based on maternal gestational age.

\begin{tabular}{|c|c|c|c|c|c|c|c|c|c|c|}
\hline \multicolumn{11}{|c|}{ Category } \\
\hline \multirow[t]{2}{*}{$\begin{array}{c}\text { Gestational } \\
\text { Age }\end{array}$} & \multicolumn{2}{|c|}{ No Anxiety } & \multicolumn{2}{|c|}{ Mild Anxiety } & \multicolumn{2}{|c|}{$\begin{array}{l}\text { Moderate } \\
\text { Anxiety }\end{array}$} & \multicolumn{2}{|c|}{$\begin{array}{l}\text { Severe } \\
\text { Anxiety }\end{array}$} & \multicolumn{2}{|c|}{ Total } \\
\hline & $\mathrm{N}$ & $\%$ & $\mathrm{~N}$ & $\%$ & $\mathrm{n}$ & $\%$ & $\mathrm{n}$ & $\%$ & $\mathrm{n}$ & $\%$ \\
\hline Trimester I & 41 & 51.2 & 35 & 43.8 & 3 & 3.8 & 1 & 1.2 & 80 & 100 \\
\hline Trimester II & 25 & 65.8 & 12 & 31.6 & 1 & 2.6 & 0 & 0 & 38 & 100 \\
\hline Trimester III & 23 & 63.9 & 11 & 30.6 & 1 & 2.8 & 1 & 2.8 & 36 & 100 \\
\hline Total & \multicolumn{2}{|c|}{89} & \multicolumn{2}{|c|}{58} & \multicolumn{2}{|c|}{5} & \multicolumn{2}{|c|}{2} & \multicolumn{2}{|c|}{154} \\
\hline
\end{tabular}

Source: Primer data, 2020

From the exposure of these data, it is concluded that the group with the most no anxiety category was in the second-trimester pregnant women, the mildest and moderate anxiety categories were in the first-trimester group, and the severe anxiety category was in the third-trimester pregnant women group.

Chi-square test results showed a value of $p=0.66$ which means there was no relationship between gestational age with anxiety in pregnant women during the pandemic era of COVID-19. This finding is similar to that found by other researchers in studies conducted in Italy and in Australia that gestational age had no significant association with anxiety; however, it was more frequent in the last trimester of pregnancy $(11,14)$.

\section{Increase based on the respondent's education}

Table 3 shows the level of anxiety of respondents based on their level of education which is classified into 2 levels namely low and high. From the results of statistical tests with the characteristics of the education level of pregnant women shows that the majority of respondents with high education that is equal to 102 respondents $(66.23 \%)$. Education and knowledge are two things that are always juxtaposed. Based on the results of statistical tests it was found that of the 102 highly educated respondents there were 2 respondents $(2.0 \%)$ who had severe anxiety levels and 3 respondents $(2.9 \%)$ who had moderate anxiety levels. In respondents with low education levels, out of 52 respondents, there were 2 respondents (3.8\%) with moderate anxiety levels and 23 respondents (44.2\%) with mild anxiety levels. 
Table 3. Distribution of anxiety based on the respondent's educational status

\begin{tabular}{|c|c|c|c|c|c|c|c|c|c|c|}
\hline \multirow{3}{*}{ Education } & \multicolumn{9}{|c|}{ Category } & \\
\hline & \multicolumn{2}{|c|}{ No Anxiety } & \multicolumn{2}{|c|}{ Mild Anxiety } & \multicolumn{2}{|c|}{$\begin{array}{l}\text { Moderate } \\
\text { Anxiety }\end{array}$} & \multicolumn{2}{|c|}{$\begin{array}{c}\text { Severe } \\
\text { Anxiety }\end{array}$} & \multicolumn{2}{|c|}{ Total } \\
\hline & $\mathrm{N}$ & $\%$ & $\mathrm{~N}$ & $\%$ & $\mathrm{~N}$ & $\%$ & $\mathrm{~N}$ & $\%$ & $\mathrm{n}$ & $\%$ \\
\hline Low & 27 & 51.9 & 23 & 44.2 & 2 & 3.8 & 0 & 0 & 52 & 100 \\
\hline Higher & 62 & 60.8 & 35 & 34.3 & 3 & 2.9 & 2 & 2.0 & 102 & 100 \\
\hline Total & \multicolumn{2}{|c|}{89} & \multicolumn{2}{|c|}{58} & \multicolumn{2}{|c|}{5} & \multicolumn{2}{|c|}{2} & \multicolumn{2}{|c|}{154} \\
\hline
\end{tabular}

From these data, it can be concluded that the group with no anxiety category is the respondent with higher education, the category of mild and moderate anxiety is mostly in the low education respondent group and the most severe anxiety is in the higher education respondent group.

The results of the chi-square test showed that the value of $p=0.48$, which means there is no relationship between education level and anxiety in pregnant women during the COVID-19 pandemic era. This is in line with Strijobs' research which states that respondents with higher education do have lower levels of anxiety but there is no significant relationship between education and anxiety levels. This result is associated with the ability of each respondent to process the information obtained. Respondents with higher education are expected to be able to process information better than respondents with low education, but there are other factors that can cause a person's ability to process information such as health and the social environment (15).

\section{Level of anxiety based on job}

Table 4 shows the level of anxiety of respondents based on the job category which is divided into 2 namely unemployment and employee. The results of statistical tests with job characteristics show that the majority of respondents work namely 86 respondents $(55.84 \%)$. Based on the results of the study found that of the 86 respondents who worked there were 2 respondents $(2.3 \%)$ with severe anxiety and 3 respondents (3.5\%) moderate anxiety. Respondents who did not work a total of 68 respondents $(44.15 \%)$, there were as many as 2 respondents $(2.9 \%)$ with moderate anxiety and 27 respondents $(39.7 \%)$ with mild anxiety.

Table 4. Distribution of anxiety based on work.

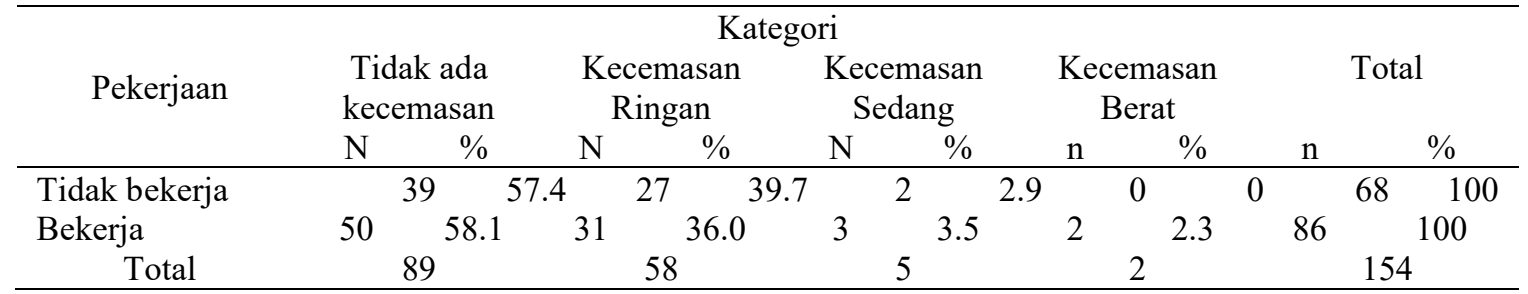

From these data, it can be concluded that the group with the category of no anxiety, moderate anxiety, and severe anxiety is mostly in the working respondent group while mild anxiety is in the non-working respondent group. The results of the chi-square test showed that the value of $p=0.625$, which means that there is no relationship between the level of anxiety and the respondent's job. This result is in line with the research of Babanazari et al, Sadeghi et al. and Alipur et al. which states no relationship was found between employment status and pregnancy anxiety $(16,17)$

\section{Anxiety based on the area of domicile}

Table 5 shows the distribution of anxiety levels based on the respondent's domicile area. The results of statistical tests with the characteristics of the area of domicile of the respondents showed that the majority of respondents came from Sulawesi, namely 78 respondents $(50.64 \%)$. Based on the results of the study it was found that 78 respondents who came from Sulawesi obtained respondents with severe anxiety of 1 respondent $(1.3 \%)$ and anxious were 2 respondents $(2.6 \%)$. Respondents from Java, 36 respondents $(23.37 \%)$, there were 2 respondents $(5.6 \%)$ with moderate anxiety, and 13 respondents $(36.1 \%)$ with mild anxiety. The respondents come from Kalimantan as many as 14 respondents $(9.09 \%)$, there were as many as 1 respondents $(7.1 \%)$ with severe anxiety and 4 respondents $(28.6 \%)$ with mild anxiety. The respondents from Papua as many as 11 respondents $(7.14 \%)$, there were as many as 5 respondents $(45.5 \%)$ with mild anxiety. Among respondents from Sumatra, 10 were respondents $(6.49 \%)$, there were 1 respondent $(10.0 \%)$ 
with moderate anxiety and 4 respondents (40\%) with mild anxiety. Respondents from Maluku as many as 5 respondents (3.24\%), there were as many as 2 respondents (40\%) with mild anxiety.

Table 5. Distribution based on domicile area

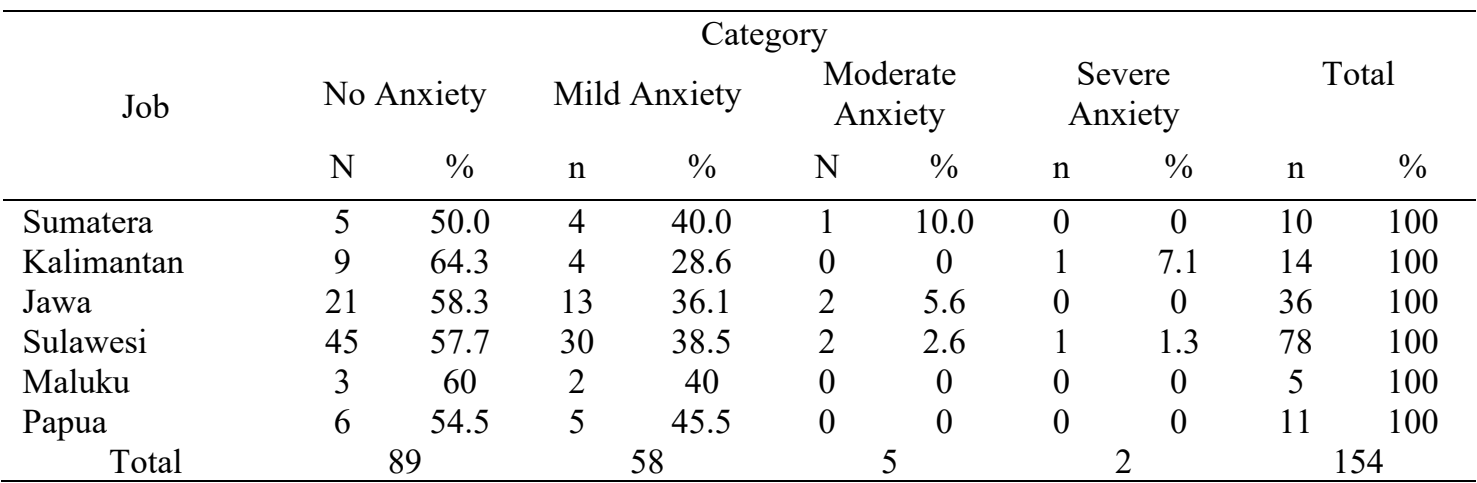

From the data, it can be ignored that the category of no respondent and assessing the weight comes from the domicile area of Kalimantan. The lightest rating category came from Papua and moderate correction came from respondents with a domicile of Sumatra. The results of the chi-square test showed that the value of $p=$ 0.909, which means that there is no relationship between the level of the respondent's domicile area. The results of this study are consistent with the research of Ravaldi et al. in Italy which suggests that the reporting rate is higher among pregnant women in areas with a small number of confirmed cases of Covid-19 (18).

\section{Discussion}

\section{Gestational Age}

The results of data analysis showed that there was no relationship between gestational age and anxiety levels in pregnant women during the Covid-19 pandemic, but respondents with severe anxiety were in the third-trimester group. Higher levels of anxiety in the third trimester were associated with closer delivery. This can be explained by the fact that pregnancy and childbirth are perceived by some pregnant women as moments of vulnerability, capable of triggering feelings of fear in women, which can be present even in women who have experienced previous births. The feeling of fear can be exacerbated with the approaching moment of the child's birth, even though it is expected throughout gestation, thus predisposing the pregnant woman to changes in her psychological well-being, since the literature demonstrates that women who are afraid of childbirth may be at greater risk of developing anxiety during pregnancy (11)

\section{Education}

The results of the data analysis showed that there was no significant relationship between the level of education and pregnant women during the Covid-19 pandemic. Pregnant women with higher education are the group with the category not having the highest number. Given the findings of this study, it can be said that higher education through intermediaries improves mental health in every period of life. Higher education improves emotional and cognitive and intellectual skills to deal with stress and life difficulties, broadens one's social network, and reduces the risk of psychiatric disorders such as anxiety in different life situations. It is worth mentioning that more knowledge and information sometimes prepares the ground for increased anxiety because ignorance of a phenomenon can lead to anxiety. This could be the reason for the disagreement between this finding and other studies (17)

\section{Profession}

The results of statistical analysis showed that there was no significant relationship between work status and the level of pregnant women during the Covid-19 pandemic. There was no largest mass category, namely in the group of pregnant women, although, on the other hand, the weight category was also in this group.Several studies have shown that the rate in pregnant women working is much lower than that of unemployed pregnant women because work is a strong protective factor against major depression in pregnancy. what to do regarding their own health (19) 


\section{Area of domicile}

The results of statistical tests show that there is no relationship between the level of pregnant women and the area of residence of the respondent. Anxiety actually occurs in respondents who come from areas that are not included in the red zone (3). Research with similar results was conducted by Ravadi et al, who stated that the rate of pregnant women in areas with fewer Covid-19 cases was actually higher. This happens with expressions of fear and a form of anticipation of the increase in cases that continue to occur in other areas including the Red Zone (18)

\section{Anxiety}

The results of statistical tests showed that more than $50 \%$ of pregnant women were included in the non-existent category during the Covid-19 pandemic. The researcher tried to summarize some of the causes for the high number of categories with no anxiety in the respondents, namely :

1) The dissemination of information is carried out by the government through various media so that it is easily accessible to the public about the causes, modes of transmission, and prevention of Covid-19, which lowers the level of society, especially pregnant women. Research conducted by Janet, et al., Shows that providing information can reduce the rate of reduction (20)

2) The government guarantees service and rewards for health facilities. Even though during the Covid-19 pandemic there were suggestions for pregnant women to carry out antenatal care checks, health facilities and government service guarantees will make pregnant women feel calm regarding the continuity of their pregnancy. Limited access to health facilities is a strong predictive factor for depression and anxiety. Women who have difficulty accessing health facilities are six to seven times more likely to experience depression and anxiety than those who have easy access to health facilities (21)

However, apart from the second factor that the research team mentioned, in reality, the four variables (age of the pregnancy, education, occupation, and area of domicile) were related to one another. Mothers with second-trimester pregnancies who theoretically have low levels, but live in the red zone and have low education, which can turn into anxiety due to the inability to process and implement existing information and vice versa

\section{CONCLUSION}

The results showed the low number of pregnant women during the Covid-19 pandemic in Indonesia which was based on the dissemination of information about the causes, modes of transmission, and prevention of massive Covid-19 carried out through various media as well as the guarantee of health services and facilities by the Indonesian government.Although the results of this study indicate a low number in pregnant women, the mental health of pregnant women needs to pay special attention to the special attention that is assessed when the pregnancy is carried out in health. A better understanding of the psychological impact of the Covid-19 pandemic remains to be done with further research, one of which is by developing research instruments and in-depth interview methods to get a better picture of the mental health conditions of pregnant women during the Covid-19 pandemic.

\section{ACKNOWLEDGEMENTS}

The researchers would like thank to all parties involved in this research. This research was funded by a grant from the Institute for Research and Community Service at the University of Borneo Tarakan.

\section{REFERENCES}

[1] Panahi L, Amiri M, Pouy S. Risks of Novel Coronavirus Disease (COVID-19) in Pregnancy; a Narrative Review. Arch Acad Emerg Med [Internet]. 2020;8(1):e34. Available from:

http://www.ncbi.nlm.nih.gov/pubmed/32232217

[2] Cucinotta D, Vanelli M. WHO declares COVID-19 a pandemic. Acta Biomedica. 2020.

[3] Gugus Tugas Percepatan Penanganan Covid-19. Pedoman Penanganan Cepat Medis dan Kesehatan Masyarakat Covid-19 di Indonesia [Internet]. 23 Maret. 2020. 1-38 p. Available from:

http://www.covid19.go.id

[4] Kemenkes RI. Pedoman Pencegahan dan Pengendalian Coronavirus Disease (COVID-19). Germas. 2020;0- 
115.

[5] POGI. Rekomendasi Penanganan Infeksi Virus Corona (COVID-19) Pada Maternal (Hamil, Bersalin, dan Nifas). Perkumpulan Obstet dan Ginekol Indones. 2020;

[6] Durankuş F, Aksu E. Effects of the COVID-19 pandemic on anxiety and depressive symptoms in pregnant women: a preliminary study. J Matern Neonatal Med. 2020;

[7] Fakari FR, Simbar M. Coronavirus pandemic and worries during pregnancy; a letter to editor. Archives of Academic Emergency Medicine. 2020.

[8] Canadian Mental Health Association BD. COVID-19 and Anxiety. In: 2020 [Internet]. Heretohelp; Available from: https://www.heretohelp.bc.ca/infosheet/covid-19-and-anxiety

[9] Kajdy A, Feduniw S, Ajdacka U, Modzelewski J, Baranowska B, Sys D, et al. Risk factors for anxiety and depression among pregnant women during the COVID-19 pandemic: A web-based cross-sectional survey. Medicine (Baltimore). 2020;

[10] Dunkel Schetter C, Tanner L. Anxiety, depression and stress in pregnancy: Implications for mothers, children, research, and practice. Current Opinion in Psychiatry. 2012.

[11] Silva MM de J, Nogueira DA, Clapis MJ, Leite EPRC. Anxiety in pregnancy: Prevalence and associated factors. Rev da Esc Enferm. 2017;51(September).

[12] Yulianti I, Respati SH, Sudiyanto A. The Effect of Prenatal Yoga on Anxiety and Depression in Kudus, Central Java. J Matern Child Heal. 2018;

[13] Saccone G, Florio A, Aiello F, Venturella R, De Angelis MC, Locci M, et al. Psychological impact of coronavirus disease 2019 in pregnant women. American Journal of Obstetrics and Gynecology. 2020.

[14] Rallis S, Skouteris H, McCabe M, Milgrom J. A prospective examination of depression, anxiety and stress throughout pregnancy. Women and Birth. 2014;

[15] Strijbos J. Educational level as a predictor for anxiety and depression in ICD-patients. 2016;(June):1-19.

[16] Laleh Babanazari 1 MKDS. Relationship of Pregnancy Anxiety to its Different Periods, Sexual Satisfaction and Demographic Factors. Iran J Psychiatry Clin Psychol [Internet]. 2008;14(2 (8-2008)):206-2013. Available from: http://ijpcp.iums.ac.ir/browse.php?a_id=473\&sid=1\&slc_lang=en

[17] Nekoee T, Zarei M. Evaluation the Anxiety Status of Pregnant Women in the Third Trimester of Pregnancy and Fear of Childbirth and Related Factors. Br J Med Med Res. 2015;9(12):1-8.

[18] Ravaldi C, Wilson A, Ricca V, Homer C, Vannacci A. Pregnant women voice their concerns and birth expectations during the COVID-19 pandemic in Italy. Women and Birth [Internet]. 2020;(2019). Available from: https://doi.org/10.1016/j.wombi.2020.07.002

[19] Fall A, Goulet L, Vézina M. Comparative study of major depressive symptoms among pregnant women by employment status. Springerplus. 2013;

[20] Kloos JA, Daly BJ. Effect of a family-maintained progress journal on anxiety of families of critically ill patients. Critical Care Nursing Quarterly. 2008.

[21] Anwar J, Mpofu E, Matthews LR, Shadoul AF, Brock KE. Reproductive health and access to healthcare facilities: Risk factors for depression and anxiety in women with an earthquake experience. BMC Public Health [Internet]. 2011;11(1):523. Available from: http://www.biomedcentral.com/1471-2458/11/523 